Research article

\title{
Occupation and skin cancer: the results of the HELIOS-I multicenter case-control study
}

\author{
Berta Suárez ${ }^{\dagger 1}$, Gonzalo López-Abente* ${ }^{* 1}$, Carmen Martínez ${ }^{2}$, \\ Carmen Navarro ${ }^{3}$, Maria José Tormo ${ }^{3}$, Stefano Rosso ${ }^{4}$, Simon Schraub ${ }^{5}$, \\ Lorenzo Gafá ${ }^{6}$, Hélène Sancho-Garnier ${ }^{7}$, Janine Wechsler ${ }^{8}$ and \\ Roberto Zanetti ${ }^{4}$
}

\begin{abstract}
Address: ${ }^{1}$ Environmental and Cancer Epidemiology Unit, National Center for Epidemiology, Carlos III Institute of Health, Sinesio Delgado 6, 28029 Madrid, Spain, ${ }^{2}$ Andalusian School of Public Health, Granada, Spain, ${ }^{3}$ Directorate-General for Public Health, Murcia, Spain, ${ }^{4}$ Registro Tumori Piemonte, Turin, Italy, ${ }^{5}$ Centre de lutte contre le cancer Paul Strauss, Université Luis Pasteur, 67000 Strasbourg, France, ${ }^{6}$ Lega Italiana per la lotta contro I tumori Sezione provinciale Ragusa. Ragusa, Italy, ${ }^{7}$ Epidaure, Montpellier, France and ${ }^{8}$ Service d'Anatomie et de Cytologie Pathologiques, Hospital Henry Mondor, 94010 Créteil, France

Email: Berta Suárez - bsuarez@isciii.es; Gonzalo López-Abente* - glabente@isciii.es;

Carmen Martínez - carmen.martinez.easp@juntadeandalucia.es; Carmen Navarro - Carmen.Navarro@carm.es;

Maria José Tormo - mjose.tormo@carm.es; Stefano Rosso - Stefano.Rosso@cpo.it; Simon Schraub - simon.schraub@free.fr;

Lorenzo Gafà - lorenzo.gafa@tin.it; Hélène Sancho-Garnier - Helene.Sancho-Granier@valdorel.fnclcc.fr;

Janine Wechsler - janine.wechsler@hmn.ap.hop.paris.fr; Roberto Zanetti - Roberto.zanetti@cpo.it

* Corresponding author †Equal contributors
\end{abstract}

Published: 26 July 2007

BMC Public Health 2007, 7:180 doi:10.1 186/147I-2458-7-180

This article is available from: http://www.biomedcentral.com/I47/-2458/7//80

(c) 2007 Suárez et al; licensee BioMed Central Ltd.

This is an Open Access article distributed under the terms of the Creative Commons Attribution License (http://creativecommons.org/licenses/by/2.0), which permits unrestricted use, distribution, and reproduction in any medium, provided the original work is properly cited.

\begin{abstract}
Background: Non-melanoma skin cancer (NMSC) is the most frequent tumour among Caucasian populations worldwide. Among the risk factors associated with this tumour, there are host-related factors and several environmental agents. A greater likelihood of high exposure to physical agents (with the exception of solar radiation) and chemical agents depends on the work setting. Our objective is to evaluate the role of occupational exposures in NMSC, with special emphasis on risk factors other than solar radiation and skin type.
\end{abstract}

Methods: We analysed I585 cases (I333 basal cell carcinoma (BCC) and I83 squamous cell carcinoma (SCC)) and I507 controls drawn from the Helios-I multicenter study. Odds ratios (OR) and $95 \%$ confidence intervals $(\mathrm{Cl})$ were estimated using logistic regression mixed models.

Results: For NMSC as a whole (both histological types), miners and quarrymen, secondary education teachers, and masons registered excess risk, regardless of exposure to solar radiation and skin type (OR 7.04, 95\% Cl 2.44-20.3I; OR I.75, 95\% Cl I.05-2.89 and OR $1.54,95 \% \mathrm{Cl} 1.04-2.27$, respectively). Frequency of BCC proved higher among railway engine drivers and firemen (OR 4.55; 95\% Cl 0.96-21.57), specialised farmers (OR I.65; 95\% Cl I.05-2.59) and salesmen (OR 3.02; 95\% Cl I.052.86 ), in addition to miners and quarrymen and secondary education teachers (OR 7.96; $95 \% \mathrm{Cl} 2.72-23.23$ and OR I.76; $95 \%$ CI 1.05-2.94 respectively). The occupations that registered a higher risk of SCC (though not of BCC) were those involving direct contact with livestock, construction workers not elsewhere classified (OR 2.95, 95\% Cl I.12-7.74), stationary engine and related equipment operators not elsewhere classified (OR 5.3I, 95\% Cl I.I3-2I.04) and masons (OR 2.55, 95\% Cl I.36-4.78).

Conclusion: Exposure to hazardous air pollutants, arsenic, ionizing radiations and burns may explain a good part of the associations observed in this study. The Helios study affords an excellent opportunity for further in-depth study of physical and chemical agents and NMSC based on matrices of occupational exposure. 


\section{Background}

Non-melanoma skin cancer is the most frequent tumour among Caucasian populations worldwide. Nevertheless, the study of its frequency poses difficulties. As one of the basic data sources for identification of cases in population cancer registries are hospital and pathology records, the fact that non-melanoma skin cancer is often not grounds for hospital admission may well lead to under-registration of cases. Furthermore, being a disease that can progress with few symptoms and is basically manifested in persons of advanced age, it may never be diagnosed. Cure rates stand at around $99 \%$ [1], with the result that it is a tumour to which relatively little attention is paid and is often not included among cancers targeted by population cancer registries. Variability in incidence rates is very marked, something that might in part be due to greater or lesser comprehensiveness of the case registry, as well as differences in risk among populations. The highest European incidence rates correspond to cancer registries in Ireland and Geneva (Switzerland), with rates close on 100 per 100,000 population [2]. In surveys conducted in Australia, annual incidence rates were estimated to exceed 1,000 per 100,000 population $[3,4]$.

In all, $80-85 \%$ of non-melanoma skin cancers are basal cell carcinomas (BCC) and the remaining percentage are squamous cell carcinomas (SCC), with the latter being the more invasive of the two and underlying most of the deaths attributable to these tumours [5]. Both histologic types consistently register a positive relationship with exposure to solar ultraviolet (UV) radiation and an inverse relationship with the degree of skin pigmentation in the population [6], though differences nevertheless do exist between the two histologic types in terms of risk of presenting with cancer by type of exposure (brief-intense in basal cell, and prolonged-accumulated in squamous cell carcinomas) [7]. Among the risk factors associated with this tumor, there are host-related factors, such as skin pigmentation, precursor lesions (actinic keratosis or Bowen's disease), genetic predisposition, and immunologic factors. Physical agents (ultraviolet and ionizing radiations) [8-11] and chemical agents (polycyclic aromatic hydrocarbons, arsenic, and nitrosamines) [12-15], as well as diet-related factors, viruses and the predisposition generated by certain traumas, burns and scars have been identified as environmental etiologic agents [16-18].

A greater likelihood of high exposure to physical agents (with the exception of solar radiation) and chemical agents depends on the work setting. Hence, this study sought to evaluate the role of occupational exposures in non-melanoma skin cancer, with special emphasis on risk factors other than solar radiation, using data drawn from the Helios-I multicenter study for the purpose $[7,8]$. Such additional factors are connected with exposures to envi- ronmental chemical substances (e.g., chimney soot, arsenic compounds, polycyclic hydrocarbons), chronic skin irritation, viral infections, and immune factors that can predispose to this type of cancer [19-23].

\section{Methods}

The Helios I study was a European multicenter case-control study. Its design is briefly outlined below, with a more detailed description to be found in the reference section $[7,8]$

\section{Selection of cases}

We included all cases of non-melanoma skin cancer registered from November 1989 through June 1993 in the following 6 European regions: Turin (north-west Italy); Ragusa (Sicily); Trento (North-East Italy); Villejuif and Créteil (Paris); Besançon (Franche-Comté, France); Murcia (south-east Spain); and Granada (Andalusia, Spain). In Turin, Ragusa, Besançon, Murcia and Granada, population cancer registers that covered a total population of 3.5 million were used as the case source. In these areas, all incident cases aged 20 to 70 years with diagnosis of BCC, SCC or skin carcinoma identified by the reporting systems, were deemed eligible. In Paris, case data were collected at two specialist centers, the Gustave-Roussy Institute in Villejuif and the Henri Mondor Hospital in Créteil. Dermatologists as well as general practitioners asked cases for their consent to being interviewed on lifestyle and health. In population-based centers, cases were interviewed at the dermatology clinic itself or at home, whereas at hospital-based centers, they were interviewed during their stay in hospital. Morphologic diagnoses were validated by a panel of pathologists who carried out a blind review of the biopsies [24].

\section{Selection of controls}

The group of controls was obtained by random sampling, duly stratified by age and sex, and conducted in the same regions in which the cases were recruited. The strata were proportional to the distribution of cases by age and sex. The sample was recruited on the basis of electoral censuses in Ragusa and Besançon and municipal rolls in Turin, Murcia and Granada. In the case of Paris, the controls were obtained by means of random sampling, based on hospital registers and excluding all patients with cancer or skin diseases. Controls were contacted by letter, and interviewed at home, in the workplace, or at the cancer registry. In the case of hospital controls, such interviews took place during their stay in hospital.

\section{Assessment of exposure}

Questionnaires were completed during an interview conducted by purpose-trained staff. A section of the questionnaire recorded information on participants' work history, i.e., any job held during their lifetime with a minimum 
Table I: Number of persons included in this analysis, by center and histologic type

\begin{tabular}{|c|c|c|c|c|c|}
\hline Center & Total number & Cases & BCC & SCC & Controls \\
\hline Granada & 626 & 310 & 263 & 33 & 316 \\
\hline Murcia & 548 & 295 & 228 & 57 & 253 \\
\hline Besançon & 495 & 247 & 203 & 28 & 248 \\
\hline Villejuif & 196 & 98 & 82 & 11 & 98 \\
\hline Créteil & 190 & 95 & 80 & 12 & 95 \\
\hline Turin & 829 & 432 & 400 & 24 & 397 \\
\hline Ragusa & 208 & 108 & 77 & 18 & 100 \\
\hline Total & 3092 & 1585 & 1333 & 183 & 1507 \\
\hline
\end{tabular}

BCC: basal cell carcinomas

SCC: squamous cell carcinomas

In 69 cases there was no record of histologic type

duration of 6 months. They were asked about the type of work, the firm's activity, and the starting and finishing dates. In addition, this section included questions on outdoor work performed, hours per day and months worked in the periods May-September or October-April, whether subjects worked partly unclothed, whether they wore a head covering and, lastly, whether they wore socks or stockings during work done in summer. Another sections reported on participants' use of leisure time, and on their phenotype characteristics.

Occupations were classified and coded according to the International Standard Classification of Occupations (ISCO) [25]. Analyses were performed for 10 major occupational groups, defined by the first of the four digits code, and for occupations defined by the first three digits of the code. We selected a total of 157 three-digit occupations having a minimum of five exposed individuals with at least one case and one control.

Insofar as the "exposure to sun" variable was concerned, this was measured on a continuous scale, as total hours, in terms of solar exposure during vacations and during outdoor work, weighted and not weighted by season of exposure (on average, solar irradiation in summer is double that in winter). Quartiles were calculated and the "exposure to sun" variable categorized on this basis. A complete explanation of sun exposure recording can be consulted on Rosso et al. [7].

In addition, the models also included variables that had proven to be independent risk indicators in previous analyses $[7,8,26]$, namely: color of eyes; natural hair color at age 20 years; and reaction of skin to solar exposure (history of sunburn). References to "phenotype" in the text are to these three components.

In the analysis, we assessed the effect of occupation on appearance of basal cell and squamous cell carcinomas, considered jointly and singly. ORs and their 95\% confidence intervals $(\mathrm{CI})$ were calculated using unconditional logistic regression mixed models. In a first analysis, estimates were adjusted for age and sex (variables matched by frequency), with exposure to solar radiation and phenotype being added subsequently. Center/town was included as a random effects term in all analyses [27].

At the time the study has been conducted ethical approval was not required for epidemiological studies in none of the involved countries. Written consent was obtained from every recruited subject, in order to both analyzing the data acquired and accessing the relevant diagnostic documents (e.g. pathology reports).

\section{Results}

The participation rate, as described elsewhere [8] was $85.8 \%$ among cases and $69.3 \%$ among controls. For this analysis, we included 3092 participants, with 1585 cases and 1507 controls. We excluded 297 cases and 288 controls since information on occupation was not available. Among the cases, 1333 presented with basal cell, and 183 with squamous cell carcinoma. Mean age was 60.5 years for cases and 58.2 years for controls. A total of $63 \%$ of cases and $62 \%$ of controls were men. Shown in Table 1 is the breakdown of the study by participant region, from which it will be seen that Turin was the region with the greatest contribution to the study, followed by Granada, Murcia and Besançon.

Table 2 shows the results of the analysis by major occupational group, defined by the first digit of the ISCO code, for: a) all cases; b) basal cell carcinomas; and, c) squamous cell carcinomas. Two effect estimates are shown, one adjusted for age and sex, and the other additionally adjusted for solar exposure and phenotype. Both estimates are adjusted for center as a random effects term (amounting to a conservative constraint). The analysis by major group yielded no statistically significant associa- 
Table 2: Effect of occupation (major groups) on non-melanoma skin cancers. OR and $95 \%$ confidence intervals. Estimates adjusted for a) age group, sex and center; b) age group, sex, exposure to sun, skin type and center. All cases, basal cell and squamous cell

\begin{tabular}{|c|c|c|c|c|c|c|c|}
\hline & & \multicolumn{6}{|c|}{ TOTAL CASES } \\
\hline & & \multirow[b]{2}{*}{ Exp } & \multirow[b]{2}{*}{ No exp } & \multicolumn{2}{|c|}{$\begin{array}{l}\text { Adjusted for } \\
\text { age and sex }\end{array}$} & \multicolumn{2}{|c|}{$\begin{array}{c}\text { Adjusted for age, sex, } \\
\text { exposure to sun, and } \\
\text { skin type }\end{array}$} \\
\hline & & & & OR & $95 \% \mathrm{Cl}$ & OR & $95 \% \mathrm{Cl}$ \\
\hline \multirow{2}{*}{$\begin{array}{l}\text { Physical scientists, architects and engineers, biological and health scientists, } \\
\text { mathematicians and economists }\end{array}$} & Cases & 129 & 1455 & 1.28 & $0.98-1.69$ & 1.21 & $0.91-1.62$ \\
\hline & Controls & 98 & 1407 & & & & \\
\hline \multirow[t]{2}{*}{ Accountants, jurists, teachers, writers and artists } & Cases & 185 & 1400 & 1.13 & $0.90-1.41$ & 1.11 & $0.88-1.40$ \\
\hline & Controls & 158 & 1349 & & & & \\
\hline \multirow[t]{2}{*}{ Administrative and managerial workers } & Cases & 60 & 1524 & 1.32 & $0.88-1.97$ & 1.30 & $0.86-1.96$ \\
\hline & Controls & 43 & 1464 & & & & \\
\hline \multirow[t]{2}{*}{ Clerical and related workers } & Cases & 287 & 1295 & 0.93 & $0.77-1.11$ & 0.88 & $0.73-1.07$ \\
\hline & Controls & 292 & 1212 & & & & \\
\hline \multirow[t]{2}{*}{ Sales workers } & Cases & 176 & 1406 & 0.90 & $0.72-1.13$ & 0.89 & $0.7 I-1.1 I$ \\
\hline & Controls & 185 & $|32|$ & & & & \\
\hline \multirow[t]{2}{*}{ Service workers } & Cases & 283 & 1302 & 0.85 & $0.71-1.02$ & 0.85 & $0.7 I-1.02$ \\
\hline & Controls & 308 & 1196 & & & & \\
\hline \multirow[t]{2}{*}{ Agriculture, animal husbandry and fishermen } & Cases & 486 & 1097 & 1.06 & $0.91-1.25$ & 1.18 & $0.96-1.45$ \\
\hline & Controls & 436 & 1069 & & & & \\
\hline \multirow[t]{2}{*}{ Miners, metalworker, woodworkers, chemical workers } & Cases & 288 & 1297 & 1.08 & $0.90-1.30$ & 1.12 & $0.93-1.35$ \\
\hline & Controls & 258 & 1248 & & & & \\
\hline \multirow[t]{2}{*}{ Leather workers, welders, electricians and glass workers } & Cases & 289 & 1295 & 0.91 & $0.76-1.10$ & 0.90 & $0.74-1.08$ \\
\hline & Controls & 295 & 1211 & & & & \\
\hline \multirow[t]{2}{*}{ Rubber workers, graphic artists, painters, builders, transport workers } & Cases & 431 & 1153 & 1.08 & $0.91-1.28$ & 1.10 & $0.93-1.31$ \\
\hline & Controls & 387 & 1118 & & & & \\
\hline
\end{tabular}

BASAL CELL

Physical scientists, architects and engineers, biological and health scientists, mathematicians and economists

Accountants, jurists, teachers, writers and artists

Administrative and managerial workers

Clerical and related workers

Sales workers

Service workers

Agriculture, animal husbandry and fishermen

Miners, metalworker, woodworkers, chemical workers

Leather workers, welders, electricians and glass workers

Rubber workers, graphic artists, painters, builders, transport workers

$\begin{array}{rrrrrrr}\text { Cases } & 115 & 1217 & 1.38 & 1.04-1.83 & 1.26 & 0.94-1.69 \\ \text { Controls } & 98 & 1407 & & & & \\ \text { Cases } & 152 & 1181 & 1.10 & 0.87-1.40 & 1.07 & 0.84-1.37 \\ \text { Controls } & 158 & 1349 & & & & \\ \text { Cases } & 50 & 1282 & 1.35 & 0.89-2.05 & 1.31 & 0.85-2.01 \\ \text { Controls } & 43 & 1464 & & & & \\ \text { Cases } & 253 & 1077 & 0.97 & 0.80-1.17 & 0.90 & 0.74-1.10 \\ \text { Controls } & 292 & 1212 & & & & \\ \text { Cases } & 159 & 1172 & 0.98 & 0.78-1.22 & 0.96 & 0.76-1.21 \\ \text { Controls } & 185 & 1321 & & & & \\ \text { Cases } & 246 & 1087 & 0.88 & 0.73-1.06 & 0.88 & 0.73-1.07 \\ \text { Controls } & 308 & 1196 & & & & \\ \text { Cases } & 394 & 939 & 1.04 & 0.88-1.23 & 1.21 & 0.97-1.50 \\ \text { Controls } & 436 & 1069 & & & & \\ \text { Cases } & 246 & 1087 & 1.10 & 0.90-1.33 & 1.14 & 0.93-1.39 \\ \text { Controls } & 258 & 1248 & & & & \\ \text { Cases } & 250 & 1083 & 0.96 & 0.79-1.16 & 0.93 & 0.76-1.13 \\ \text { Controls } & 295 & 1211 & & & & \\ \text { Cases } & 353 & 980 & 1.07 & 0.90-1.27 & 1.10 & 0.92-1.32 \\ \text { Controls } & 387 & 1118 & & & & \end{array}$

SQUAMOUS CELL

Physical scientists, architects and engineers, biological and health scientists, mathematicians and economists

Accountants, jurists, teachers, writers and artists

\begin{tabular}{|c|c|c|c|c|c|c|}
\hline Cases & 10 & 173 & 0.88 & $0.45-1.72$ & 0.85 & $0.40-1.80$ \\
\hline Controls & 98 & 1407 & & & & \\
\hline Cases & 16 & 167 & 0.81 & $0.46-1.43$ & 0.80 & $0.43-1.48$ \\
\hline Controls & 158 & 1349 & & & & \\
\hline
\end{tabular}


Table 2: Effect of occupation (major groups) on non-melanoma skin cancers. OR and $95 \%$ confidence intervals. Estimates adjusted for a) age group, sex and center; b) age group, sex, exposure to sun, skin type and center. All cases, basal cell and squamous cell (Continued)

\begin{tabular}{|c|c|c|c|c|c|c|c|}
\hline \multirow[t]{2}{*}{ Administrative and managerial workers } & Cases & 8 & 175 & 1.27 & $0.59-2.77$ & 1.43 & $0.61-3.32$ \\
\hline & Controls & 43 & 1464 & & & & \\
\hline \multirow[t]{2}{*}{ Clerical and related workers } & Cases & 19 & 164 & 0.55 & $0.34-0.90$ & 0.58 & $0.34-0.99$ \\
\hline & Controls & 292 & 1212 & & & & \\
\hline \multirow[t]{2}{*}{ Sales workers } & Cases & 12 & 170 & 0.48 & $0.26-0.88$ & 0.48 & $0.25-0.92$ \\
\hline & Controls & 185 & 1321 & & & & \\
\hline \multirow[t]{2}{*}{ Service workers } & Cases & 24 & 159 & 0.66 & $0.42-1.02$ & 0.65 & $0.40-1.03$ \\
\hline & Controls & 308 & 1196 & & & & \\
\hline \multirow[t]{2}{*}{ Agriculture, animal husbandry and fishermen } & Cases & 75 & 106 & 1.34 & $0.95-1.89$ & 1.00 & $0.65-1.54$ \\
\hline & Controls & 436 & 1069 & & & & \\
\hline \multirow[t]{2}{*}{ Miners, metalworker, woodworkers, chemical workers } & Cases & 30 & 153 & 1.01 & $0.67-1.53$ & 1.13 & $0.73-1.75$ \\
\hline & Controls & 258 & 1248 & & & & \\
\hline \multirow[t]{2}{*}{ Leather workers, welders, electricians and glass workers } & Cases & 30 & 152 & 0.72 & $0.47-1.10$ & 0.79 & $0.5 \mathrm{I}-1.23$ \\
\hline & Controls & 295 & 1211 & & & & \\
\hline \multirow[t]{2}{*}{ Rubber workers, graphic artists, painters, builders, transport workers } & Cases & 62 & 120 & 1.21 & $0.87-1.69$ & 1.19 & $0.83-1.70$ \\
\hline & Controls & 387 & 1118 & & & & \\
\hline
\end{tabular}

Exp : Exposed

No Exp : No exposed

tion, save for group 0 (professional, technical and related workers) in the case of basal cell carcinomas. However, this association became attenuated after adjustment for solar exposure and phenotype, and failed to attain significance. In the case of squamous cell carcinomas, the groups classified as clerical and related workers and sales workers registered a significantly lower risk than did the remaining occupations.

Tables 3 and 4 show the analysis for the three-digit occupations. We analyzed a total of 157 occupations that had a minimum number of exposed subjects, but Table 3 only lists the results of occupations that displayed statistical significance and/or an OR of 2 or higher.

\section{All tumours (Table 3)}

For the two histologic types taken jointly, the occupations that displayed an association with the disease were "Secondary education teachers" (OR 1.75, 95\%CI 1.05-2.89, p-value = 0.03), "Miners and Quarrymen" (OR 7.04, 95\%CI 2.44-20.31, p-value $=0.0003)$, "Masons" (OR $1.54,95 \% \mathrm{CI} 1.04-2.2$, p-value $=0.032)$ and "Laborers" (OR 1.37, 95\%CI 1.02-1.85, p-value = 0.04). Some occupations, such as "Cooks", "Building Caretakers", "Butchers and Meat Preparers", "Cabinetmakers", and "Electricians", registered a protective effect.

\section{Basal cell carcinomas (Table 4)}

For BCC, excess risk was located in "Secondary education teachers" (OR 1.76, 95\%CI 1.05-2.94, p-value $=0.03$ ), "Sales Engineers" (OR 3.02; 95\%CI 1.05-8.66, p-value = 0.04 ), "Specialized farmers" (OR 1.65, 95\%CI 1.05-2.59, p-value = 0.03), "Miners and Quarrymen" (OR 7.96, 95\%CI 2.72-23.23, p-value $=0.0002$ ) and "Laborers" $($ OR 1.39, 95\%CI 1.01-1.89, p-value = 0.04). "Railway
Engine Drivers and Firemen" registered a significant increase in risk (OR 5.08, 95\%CI 1.09-23.65), which subsequently lost significance on adjustment for sun and phenotype. The protective effect encompassed "Cooks", "Building Caretakers", and "Butchers and Meat Preparers".

\section{Squamous cell carcinomas (Table 4)}

For SCC, the highest risk was detected in the occupations of "Construction worker" (OR 2.95, 95\%CI 1.12-7.74, pvalue $=0.03$ ), "Stationary engine and related equipment operators" (OR 5.31, 95\%CI 1.34-21.04, p-value $=0.02$ ) and "Mason" (OR 2.55, 95\%CI 1.36-4.78, p-value $=0.03$, p-value $=0.004)$. In the case of "General farmers" (OR 1.76, 95\%CI 1.04-2.98), "Livestock Workers" (OR 2.11, 95\%CI 1.11-4.03), "Milkers" (OR 3.64, 95\%CI 1.2210.83 ) and "Miners and Quarrymen" (OR 4.98, 95\%CI 1.23-20.18), there was an increase in risk on adjustment for age and sex, yet this rise in risk ceased to be significant when adjustment was subsequently made for solar exposure and phenotype. We detected no occupation with risk less than expected.

In the analysis of the three-digit occupations by center, the excess risk in miners was concentrated in Murcia, a province that accounted for $50 \%$ of all cases exposed, with an adjusted OR of 7.85 (95\%CI, 1.57-39.26) among men. A possible high risk was also detected in Granada and Turin, but given the low frequency of this occupation, there was only one exposed control in each case. Analysis of miners by time of exposure yielded an OR of 3.62 (95\%CI 1.0113.16) for those who had worked as miners for less than 5 years, and 15.89 (95\%CI 2.10-120.35) for those who had worked for 5 years or more (trend p-value 0.0008). 
Dose-response analysis by time of exposure (no exposed, $<5$ years and 5 or more) for secondary education teachers, for masons and for laborers was statistically significant (trend p-value $0.01,0.03$ and 0.03 respectively).

In Besançon, the association was observed for secondary education teachers, with a risk of developing nonmelanoma skin carcinoma of 3.23 (95\%CI 1.02-10.23). Another center in which significant results were observed was Turin, with an OR -in this instance protective- of 0.10 (95\%CI 0.01-0.76) for cooks.

\section{Discussion}

This study analyzes the association between nonmelanoma skin cancer and ISCO-coded occupations. Analysis of the major occupational groups showed that, in the context of basal cell carcinoma, professionals and technicians have an increased risk of developing this type of cancer. When all occupations and both histologic types were analyzed jointly, miners and quarrymen, secondary education teachers and masons registered excess risk. Separate analysis of the results by type showed a higher risk of basal cell carcinoma for railway engine drivers and firemen, farmers and salesmen, in addition to the above three occupations. The occupations that registered a higher risk of SCC (though not of BCC) were those involving direct contact with livestock, and the groups encompassing other construction workers not elsewhere classified (ISCO: 959) and stationary engine and related equipment operators not elsewhere classified (ISCO: 969).

This study include all incident cases registered in five of the participating centers that account for the $88 \%$ of the cases. This design prevent the existence bias based on occupational recruitment patterns. However, one possible source of bias could be the different population bases of the control sample; although a certain degree of distortion cannot be completely ruled out, consistency among centers was checked [8] and the country proved to be a stronger confounder than study design (hospital or population basis).

Multicenter studies such as this are an example of the indication of the use of mixed models. These models take the covariance structure or interdependence of data (characteristics not registered at each study center) into account, whereas fixed effects models assume that all observations are independent. The ensuing estimates and standard errors may possibly be more conservative, but the inferences that can be drawn from the results are wider.

A major problem of this type of exploratory study is that a large number of studied associations could produce some spurious significant results, the so-called mass-significance phenomenon. In order to deal with the problem of multiple comparisons, $\mathrm{p}$-values are provided in results section. The number of statistically significant associations found exceed very little the results expected by chance, but we consider that these results in addition to the dose-response effect with exposure time for some of the occupations, could stimulate the research about the influence of occupational exposures on this tumours.

One of the aims of this analysis was to assess the risk due to exposures other than solar radiation, yet adjustment for solar radiation and phenotype did not substantially modify the effect estimates (Tables 3 and 4). Some of the associations detected were in outdoor occupations (construction workers or farmers); exposure to sun is inherent in such occupations and may thus account for the fact that adjustment has scant influence on the result. However, in the case of other occupations for which an effect was detected, such as mining, possible explanations must be sought elsewhere.

Relatively few studies have addressed occupation and exposures other than solar radiation, in the case of these tumours. In NMSC, the role of exposure to various chemical substances has been reported. Elevated risks of squamous cell carcinoma have been detected among subjects exposed to pesticides and by-products of petroleum, lubricants and other substances. In the case of basal cell carcinoma, higher risks have also been documented in subjects exposed to fiberglass dust and dry-cleaning agents [15], though stress has nonetheless been laid on the greater importance of exposure to arsenic versus other chemical substances in the etiology of these tumours [28].

It has also been reported that $2 \%$ of such tumours could be associated with exposure to radon in the UK. [29]. The results of our study show a strong association between the occupation of miner and both histologic types of NMSC, with the strength of association for BCC being double that for SCC. The explanation for this result might partly lie in the above-mentioned exposure to radon in the case of BCC [30]; and possibly lie in exposure to arsenic in the case of SCC $[13,28]$. However, a rise in risk of precancerous skin lesions has been reported among workers in open-work lignite mines, a finding that could be attributable to the long-term increase in the risk of skin cancer [31]. The OR estimations shown wide confidence intervals, reflecting some data instability and we can not discard the effect of uncontrolled confounders.

Although this type of cancer has not been shown to be more frequent in specific social groups [32], the association between NMSC and ionizing radiations has indeed been described on a number of occasions [33-36] and is reputedly greater with BCC than with SCC $[29,34]$. Occupational exposure to UV radiation among outdoor work- 
Table 3: Non-melanoma skin cancer. OR and $95 \%$ confidence intervals associated with selected occupations*

\begin{tabular}{|c|c|c|c|c|c|c|c|c|c|c|c|}
\hline \multirow[b]{2}{*}{ Code } & \multirow[b]{2}{*}{ ISCO } & \multicolumn{2}{|c|}{ Cases } & \multicolumn{2}{|c|}{ Controls } & \multicolumn{2}{|c|}{$\begin{array}{l}\text { Adjusted for age and } \\
\text { sex }\end{array}$} & \multicolumn{2}{|c|}{$\begin{array}{l}\text { Adjusted for age, sex, } \\
\text { and exposure to sun }\end{array}$} & \multicolumn{2}{|c|}{$\begin{array}{l}\text { Adjusted for age, sex, exposure } \\
\text { to sun, and skin type }\end{array}$} \\
\hline & & Exp & No Exp & Exp & No $\operatorname{Exp}$ & OR & $95 \% \mathrm{Cl}$ & OR & $95 \% \mathrm{Cl}$ & OR & $95 \% \mathrm{Cl}$ \\
\hline 034 & Engineering Technicians & 6 & 1579 & 3 & 1504 & 1.90 & $0.47-7.60$ & 1.86 & $0.46-7.49$ & 2.07 & $0.5 \mathrm{I}-8.44$ \\
\hline 067 & Pharmacist & 6 & 1579 & 2 & 1505 & 2.88 & $0.58-14.36$ & 2.81 & $0.56-14.02$ & 2.82 & $0.55-14.43$ \\
\hline 132 & Secondary Education Teachers & 46 & 1539 & 25 & 1482 & 1.80 & $1.10-2.95$ & 1.78 & $1.08-2.92$ & 1.75 & $1.05-2.89$ \\
\hline 193 & Social Workers & 5 & 1580 & 2 & 1505 & 2.47 & $0.48-12.79$ & 2.41 & $0.46-12.47$ & 2.25 & $0.42-12.16$ \\
\hline 212 & Factory Managers & 9 & 1576 & 2 & 1505 & 4.37 & $0.94-20.33$ & 4.24 & $0.91-19.74$ & 3.46 & $0.73-16.33$ \\
\hline 342 & Computer Operators & 7 & 1578 & 2 & 1505 & 3.52 & $0.73-17.01$ & 3.46 & $0.71-16.77$ & 3.07 & $0.62-15.22$ \\
\hline 399 & Clerks n.e.c. & 6 & 1579 & 3 & 1504 & 1.97 & $0.49-7.93$ & 1.96 & $0.49-7.86$ & 2.08 & $0.50-8.59$ \\
\hline 431 & Sales Engineers & 13 & 1572 & 5 & 1502 & 2.49 & $0.88-7.01$ & 2.44 & $0.87-6.89$ & 2.53 & $0.88-7.25$ \\
\hline 531 & Cooks & 8 & 1577 & 25 & $|48|$ & 0.31 & $0.14-0.69$ & 0.31 & $0.14-0.69$ & 0.34 & $0.15-0.76$ \\
\hline 551 & Building Caretakers & 12 & 1573 & 23 & 1484 & 0.50 & $0.25-1.00$ & 0.50 & $0.25-1.00$ & 0.46 & $0.23-0.95$ \\
\hline 612 & Specialized Farmers & 55 & 1530 & 36 & $|47|$ & 1.44 & $0.94-2.21$ & 1.47 & $0.95-2.26$ & 1.49 & $0.96-2.32$ \\
\hline 711 & Miners and Quarrymen & 29 & 1556 & 4 & 1503 & 6.86 & $2.40-19.6$ & 7.07 & $2.47-20.24$ & 7.04 & $2.44-20.31$ \\
\hline 728 & Galvinizers & 11 & 1574 & 4 & 1503 & 2.60 & $0.82-8.20$ & 2.58 & $0.82-8.16$ & 2.91 & $0.91-9.25$ \\
\hline 749 & Chemical Worker s & 5 & 1580 & 1 & 1506 & 4.58 & $0.53-39.39$ & 4.59 & $0.53-39.46$ & 4.51 & $0.51-39.87$ \\
\hline 773 & Butchers and Meat Preparers & 8 & 1577 & 17 & 1489 & 0.45 & $0.19-1.04$ & 0.44 & $0.19-1.04$ & 0.41 & $0.17-0.97$ \\
\hline 811 & Cabinetmakers & 3 & 1582 & 10 & 1497 & 0.28 & $0.08-1.02$ & 0.28 & $0.08-1.02$ & 0.27 & $0.07-0.99$ \\
\hline 855 & Electricians & 9 & 1576 & 20 & 1487 & 0.42 & $0.19-0.94$ & 0.42 & $0.19-0.93$ & 0.38 & $0.17-0.85$ \\
\hline 926 & Bookbinders & 7 & 1578 & 3 & 1504 & 2.26 & $0.58-8.77$ & 2.26 & $0.58-8.77$ & 2.12 & $0.53-8.46$ \\
\hline 951 & Masons & 69 & 1516 & 47 & 1460 & 1.42 & $0.97-2.08$ & 1.44 & $0.98-2.13$ & 1.54 & $1.04-2.27$ \\
\hline 983 & Railway Engine Drivers and Firemen & 10 & 1575 & 2 & 1505 & 4.55 & $0.99-20.89$ & 4.49 & $0.98-20.62$ & 4.14 & $0.89-19.29$ \\
\hline 999 & Laborers n.e.c. & 122 & 1463 & 90 & 1417 & 1.32 & $0.99-1.76$ & 1.34 & $1.00-1.80$ & 1.37 & $1.02-1.85$ \\
\hline
\end{tabular}

* Criterion: OR $>2$ or statistically significant OR (lower limit of OR adjusted for age, sex, exposure to sun and skin type $>=.9$ or upper limit $<1$ ).

ers has a direct relationship with the appearance of these types of tumours [37-40]. In our study, farmers/animal husbandry workers were observed to register an increased risk of developing both BCC and SCC, despite our efforts to adjust for exposure to solar radiation. It is well known, however, that farmers suffer from multiple exposures [41], ranging from pesticides to hazardous air pollutants (HAPs), due to their use of different types of machinery and plants. The raised risk of basal cell carcinoma among railway engine drivers and firemen has been reported in other studies [19]. Though somewhat rare, it is acknowledged that occupational skin cancer can appear in the case of scars formed as a consequence of industrial burns [21].

The results show that the possible confounding effect generated by such solar exposure is very small, since OR magnitudes varied very little after this variable was adjusted for. Phenotype likewise failed to modify risk levels, with adjustment for it leading to no important variations vis-àvis the crude effect. Moreover, we do not know the magnitude of the residual confounding effect of solar exposure. However, our questionnaire, for skin characteristics measurements and reported sun exposure history, received a validation study and there was a good reproducibility [42].

Among workers in direct contact with livestock, risk is apparently higher for SCC. Although there is a slight possibility of false diagnoses of SCC in the case of viral warts, such a problem would seem unlikely, in view of the fact that the cases were reviewed by a panel of pathologists who verified the diagnoses. These results evinced a high degree of concordance (99.5\%), with a Kappa index (KI) of 0.85 (95\%CI $0.77-0.94)$ in the assessment of the malignancy of lesions. Concordance in the differentiation of major morphologic groups, BCC and SCC was also high ( $\mathrm{KI}=0.85 ; 95 \% \mathrm{CI} 0.82-0.89)$ [24]. There is limited evidence in humans for the carcinogenicity of HPV genusbeta types in skin (squamous-cell carcinoma). In the rare case of patients with epidermodysplasia verruciformis, there is compelling evidence for the carcinogenicity of HPV genus-beta types 5 and 8 in skin (squamous-cell carcinoma)[43].

\section{Conclusion}

This study shows the association between non-melanoma skin cancer and certain occupations. For NMSC as a whole (both histologic types), miners and quarrymen, secondary education teachers, and masons register excess risk, regardless of exposure to solar radiation and phenotype. BCC proves more frequent among railway engine drivers and firemen, farmers and salesmen, in addition to the above-mentioned 3 occupations. The occupations that register a higher risk of SCC (though not of BCC) are those involving direct contact with livestock, other construction workers not elsewhere classified and stationary engine and related equipment operators not elsewhere classified. Exposure to HAPs, arsenic, ionizing radiations and burns might well explain a good part of the associations observed in this study. The Helios Project affords an excel- 


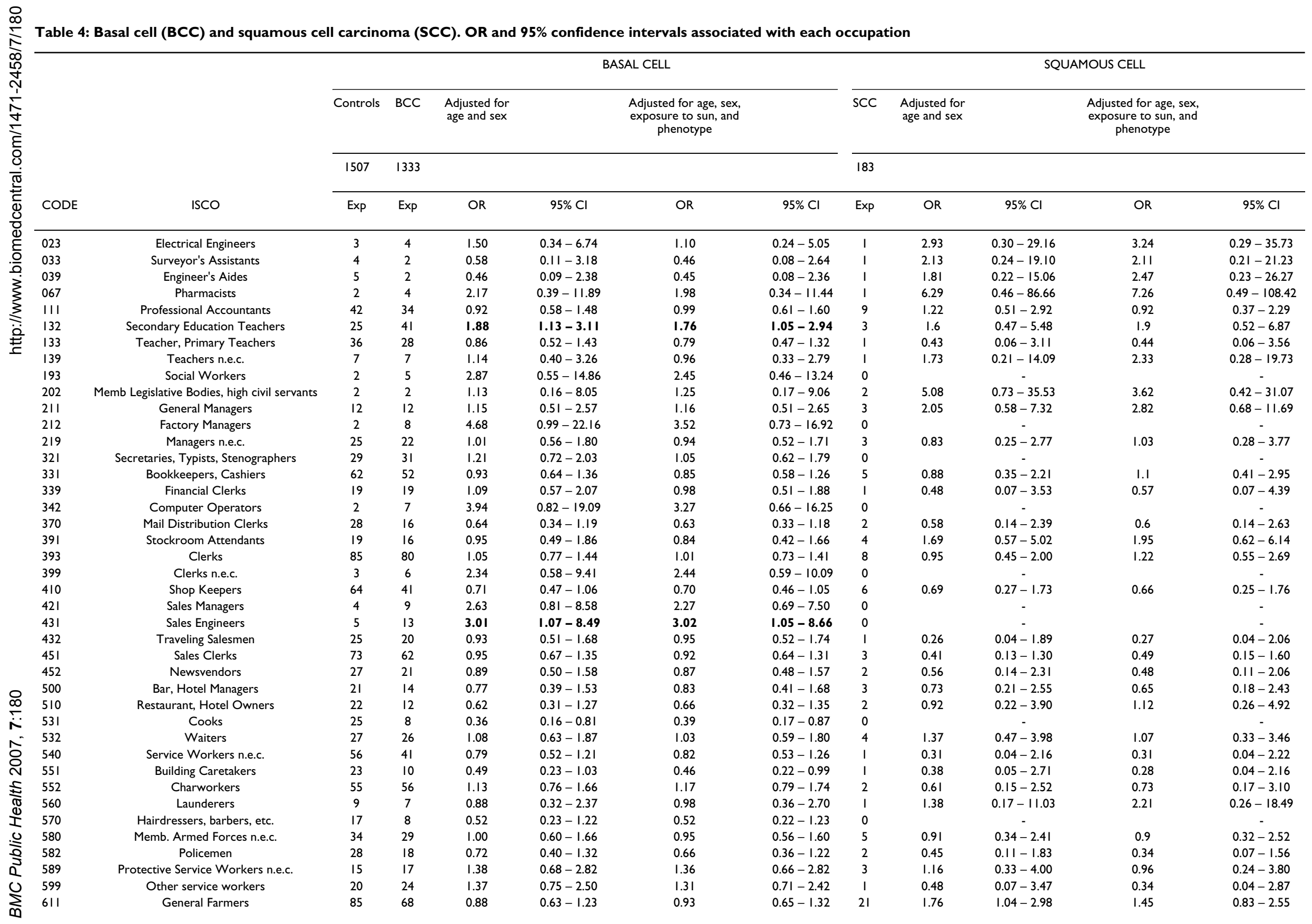


Table 4: Basal cell (BCC) and squamous cell carcinoma (SCC). OR and $95 \%$ confidence intervals associated with each occupation (Continued)

\begin{tabular}{|c|c|c|c|c|c|c|c|c|c|c|c|c|}
\hline 612 & Specialized Farmers & 36 & 48 & 1.54 & $0.99-2.39$ & 1.65 & $1.05-2.59$ & 7 & 1.06 & $0.46-2.42$ & 0.94 & $0.39-2.25$ \\
\hline 621 & General Farm Workers & 262 & 218 & 0.93 & $0.76-1.14$ & 1.04 & $0.83-1.31$ & 37 & 0.94 & $0.63-1.43$ & 0.69 & $0.44-1.09$ \\
\hline 622 & Field Crop Workers & 41 & 40 & 1.10 & $0.70-1.71$ & 1.14 & $0.72-1.79$ & 4 & 0.74 & $0.26-2.08$ & 0.65 & $0.22-1.88$ \\
\hline 623 & Palmwine Harvesters & 27 & 27 & 1.14 & $0.67-1.97$ & 1.16 & $0.67-2.01$ & 6 & 1.35 & $0.55-3.35$ & 1.45 & $0.57-3.68$ \\
\hline 624 & Livestock Workers & 42 & 32 & 0.84 & $0.52-1.35$ & 0.89 & $0.54-1.44$ & 14 & 2.11 & $1.11-4.03$ & 1.58 & $0.79-3.16$ \\
\hline 625 & Milkers & 11 & 11 & 1.16 & $0.50-2.68$ & 1.17 & $0.49-2.77$ & 5 & 3.64 & $1.22-10.83$ & 2.36 & $0.75-7.45$ \\
\hline 700 & Foremen & 27 & 26 & 1.11 & $0.64-1.91$ & 1.07 & $0.61-1.89$ & 2 & 0.47 & $0.11-1.94$ & 0.69 & $0.16-2.95$ \\
\hline 711 & Miners and Quarrymen & 4 & 25 & 7.34 & $2.54-21.20$ & 7.96 & $2.72-23.23$ & 4 & 4.98 & $1.23-20.18$ & 3.58 & $0.81-15.94$ \\
\hline 728 & Galvinizers & 4 & 8 & 2.32 & $0.69-7.73$ & 2.51 & $0.74-8.49$ & 2 & 4.08 & $0.74-22.47$ & 5.42 & $0.92-31.95$ \\
\hline 729 & Metal Processors n.e.c. & 8 & 8 & 1.14 & $0.42-3.04$ & 1.17 & $0.43-3.18$ & 2 & 1.88 & $0.39-9.06$ & 2.78 & $0.54-14.28$ \\
\hline 749 & Chemical Workers & 1 & 5 & 5.71 & $0.66-49.10$ & 5.70 & $0.65-50.42$ & 0 & & - & & - \\
\hline 773 & Butchers and Meat Preparers & 17 & 4 & 0.27 & $0.09-0.81$ & 0.26 & $0.09-0.78$ & 4 & 1.74 & $0.58-5.28$ & 1.86 & $0.54-6.34$ \\
\hline 774 & Cannery Workers & 12 & 15 & 1.40 & $0.65-3.02$ & 1.61 & $0.74-3.53$ & 2 & 1.96 & $0.43-8.93$ & 2.28 & $0.47-11.18$ \\
\hline 776 & Confectionery Makers & 22 & 13 & 0.66 & $0.33-1.32$ & 0.69 & $0.34-1.38$ & 4 & 1.51 & $0.51-4.41$ & 1.81 & $0.58-5.67$ \\
\hline 791 & Tailors and Dressmakers & 41 & 42 & 1.17 & $0.75-1.83$ & 1.19 & $0.76-1.89$ & 2 & 0.83 & $0.20-3.47$ & 1.05 & $0.24-4.55$ \\
\hline 795 & Sewing Machine Operators & 24 & 22 & 1.06 & $0.59-1.93$ & 1.06 & $0.58-1.94$ & 1 & 0.69 & $0.09-4.99$ & 0.5 & $0.06-4.14$ \\
\hline 796 & Upholsterers & 5 & 4 & 0.93 & $0.25-3.48$ & 0.94 & $0.25-3.57$ & i & 2.06 & $0.25-17.31$ & 3.58 & $0.40-31.81$ \\
\hline 832 & Tool and Die Makers & 23 & 13 & 0.64 & $0.32-1.28$ & 0.58 & $0.29-1.16$ & 1 & 0.29 & $0.04-2.08$ & 0.26 & $0.03-2.07$ \\
\hline 834 & Machine Operators in Factory & 59 & 50 & 0.96 & $0.65-1.42$ & 0.94 & $0.63-1.39$ & 5 & 0.72 & $0.29-1.8 \mid$ & 0.75 & $0.29-1.96$ \\
\hline 839 & Locksmiths & 19 & 12 & 0.72 & $0.35-1.50$ & 0.79 & $0.38-1.65$ & 3 & 1.73 & $0.50-5.92$ & 1.79 & $0.49-6.56$ \\
\hline 841 & Machinists or Fitters & 25 & 20 & 0.95 & $0.52-1.73$ & 0.85 & $0.46-1.56$ & 4 & 1.14 & $0.39-3.33$ & 1.18 & $0.39-3.62$ \\
\hline 842 & Instrument Makers & 22 & 15 & 0.76 & $0.39-1.47$ & 0.75 & $0.38-1.46$ & i & 0.41 & $0.06-2.94$ & 0.57 & $0.08-4.33$ \\
\hline 849 & $\begin{array}{l}\text { Machinery fitters, machine assemblers and } \\
\text { precision instrument makers }\end{array}$ & 45 & 40 & 1.01 & $0.65-1.56$ & 0.98 & $0.63-1.52$ & 7 & 1.42 & $0.63-3.23$ & 2.08 & $0.88-4.92$ \\
\hline 855 & Electricians & 20 & 9 & 0.51 & $0.23-1.13$ & 0.45 & $0.20-1.01$ & 0 & & - & & - \\
\hline 872 & Welders & 19 & 11 & 0.65 & $0.31-1.37$ & 0.65 & $0.30-1.39$ & I & 0.42 & $0.06-3.09$ & 0.41 & $0.05-3.16$ \\
\hline 873 & Sheet-Metal Workers & 18 & 9 & 0.57 & $0.25-1.27$ & 0.60 & $0.27-1.37$ & 0 & & - & & - \\
\hline 874 & Structural Steel Workers & 3 & 2 & 0.75 & $0.12-4.50$ & 0.89 & $0.15-5.47$ & 2 & 4.57 & $0.78-26.71$ & 2.89 & $0.33-25.50$ \\
\hline 892 & Potters & 5 & 10 & 2.33 & $0.79-6.85$ & 2.05 & $0.69-6.10$ & 0 & & - & & - \\
\hline 902 & Tire Makers and Vulcanizers & 7 & 3 & 0.49 & $0.13-1.90$ & 0.60 & $0.15-2.35$ & 2 & 2.78 & $0.58-13.38$ & 3.91 & $0.73-20.98$ \\
\hline 910 & Paper and paperboard product makers & 8 & 13 & 1.87 & $0.77-4.55$ & 1.72 & $0.69-4.25$ & 3 & 2.34 & $0.61-8.95$ & 2.47 & $0.59-10.41$ \\
\hline 922 & Printing Pressmen & 3 & 4 & 1.52 & $0.34-6.80$ & 1.63 & $0.36-7.49$ & I & 2.28 & $0.24-21.18$ & 4.06 & $0.4-41.67$ \\
\hline 926 & Bookbinders & 3 & 7 & 2.59 & $0.67-10.06$ & 2.53 & $0.64-10.08$ & 0 & & - & & - \\
\hline 931 & Painters, Construction & 16 & 18 & 1.31 & $0.66-2.58$ & 1.23 & $0.61-2.46$ & 3 & 2.06 & $0.58-7.23$ & 1.59 & $0.4 I-6.23$ \\
\hline 942 & Basketweavers & 3 & 2 & 0.75 & $0.13-4.50$ & 0.31 & $0.03-3.09$ & 1 & 3.47 & $0.36-33.69$ & 4.47 & $0.45-44.60$ \\
\hline 951 & Masons & 47 & 50 & 1.25 & $0.83-1.89$ & 1.41 & $0.93-2.14$ & 16 & 2.41 & $1.33-4.36$ & 2.55 & $1.36-4.78$ \\
\hline 954 & Carpenters & 27 & 19 & 0.81 & $0.45-1.47$ & 0.82 & $0.44-1.50$ & 4 & 1.1 & $0.39-3.14$ & 1.37 & $0.46-4.08$ \\
\hline 959 & Construction Workers & 16 & 10 & 0.70 & $0.32-1.56$ & 0.76 & $0.34-1.7$ & 7 & 2.53 & $1.03-6.23$ & 2.95 & $1.12-7.74$ \\
\hline 969 & $\begin{array}{l}\text { Stationary engine and related equipment } \\
\text { operators }\end{array}$ & 6 & 3 & 0.59 & $0.15-2.37$ & 0.73 & $0.18-2.97$ & 4 & 4.75 & $1.33-16.92$ & 5.31 & $1.34-21.04$ \\
\hline 971 & Dockers and Freight Handlers & 79 & 53 & 0.75 & $0.52-1.07$ & 0.78 & $0.54-1.12$ & 8 & 0.79 & $0.37-1.65$ & 0.83 & $0.38-1.78$ \\
\hline 973 & Crane and Hoist Operators & 7 & 4 & 0.65 & $0.19-2.23$ & 0.66 & $0.19-2.28$ & 2 & 2.09 & $0.44-10.03$ & 2.56 & $0.52-12.73$ \\
\hline 983 & Railway Engine Drivers and Firemen & 2 & 9 & 5.08 & $1.09-23.65$ & 4.55 & $0.96-21.57$ & I & 2.41 & $0.22-26.42$ & 2.86 & $0.23-35.14$ \\
\hline 985 & Drivers & 64 & 53 & 0.95 & $0.65-1.39$ & 0.95 & $0.65-1.40$ & 8 & 0.85 & $0.40-1.79$ & 0.79 & $0.37-1.73$ \\
\hline 999 & Laborers n.e.c. & 90 & 98 & 1.30 & $0.96-1.77$ & 1.39 & $1.01-1.89$ & 19 & 1.39 & $0.82-2.35$ & 1.24 & $0.71-2.18$ \\
\hline
\end{tabular}

Cannery Workers

Metal Worker

Potters

apers and Vulcanizers

related equipment

Firemen 
lent opportunity for further in-depth study based on matrices of occupational exposure.

\section{Competing interests}

The author(s) declare that they have no competing interests.

\section{Authors' contributions}

BS and GLA performed the statistical analysis and wrote the first draft of the manuscript to which all authors subsequently contributed. RZ, SR, CM, CN, MJT, HSG, JW, LG, SS were responsible for the development of intellectual content and the multicenter study design and conducting. All authors made contribution to statistical analyses and interpretation of results, and revised the manuscript for important intellectual content. All authors read and approved the final manuscript.

\section{Acknowledgements}

This study was financed in part by the Spanish Network for Cooperative Research in Epidemiology and Public Health (Red de Centros de Epidemiología y Salud Pública-RCESP) (FIS-C03/09).

\section{References}

I. Scott J, Fears R, Kraemer H, Fraumeni J: Non-melanoma skin cancer. New York: Oxford University Press; 1996: 13 13-1330.

2. Parkin DM, Whelan SL, Ferlay J, Teppo L, Thomas DB: Cancer Incidence in Five Continents Vol III. IARC Scientific Publications. IARC; 2002.

3. Diepgen TL, Mahler V: The epidemiology of skin cancer. BrJ Dermatol 2002, 146(Suppl 61): I-6.

4. Kricker A, English DR, Randell PL, Heenan PJ, Clay CD, Delaney TA, Armstrong BK: Skin cancer in Geraldton, Western Australia: a survey of incidence and prevalence. Med J Aust 1990, 152:399-407.

5. Weinstock MA: Epidemiologic investigation of nonmelanoma skin cancer mortality: the Rhode Island Follow-Back Study. J Invest Dermatol 1994, 102:6S-9S.

6. IARC: Solar and Ultraviolet Radiation. 2004 [http://mono graphs.iarc.fr/ENG/Monographs/vol55/volume55.pdf]. IARC Scientific Publications

7. Rosso S, Zanetti R, Martinez C, Tormo MJ, Schraub S, Sancho-Garnier H, Franceschi S, Gafa L, Perea E, Navarro C, Laurent R, Schrameck C, Talamini R, Tumino R, Wechsler J: The multicentre south European study 'Helios'. II: Different sun exposure patterns in the aetiology of basal cell and squamous cell carcinomas of the skin. $\mathrm{Br} J$ Cancer 1996, 73: 1447-1454.

8. Zanetti R, Rosso S, Martinez C, Navarro C, Schraub S, Sancho-Garnier $H$, Franceschi S, Gafa L, Perea E, Tormo MJ, Laurent R, Schrameck C, Cristofolini M, Tumino R, Wechsler J: The multicentre south European study 'Helios'. I: Skin characteristics and sunburns in basal cell and squamous cell carcinomas of the skin. Br J Cancer 1996, 73: 1440-1446.

9. Currie $C L$, Monk BE: Welding and non-melanoma skin cancer. Clin Exp Dermatol 2000, 25:28-29.

10. Freedman DM, Dosemeci M, McGlynn K: Sunlight and mortality from breast, ovarian, colon, prostate, and non-melanoma skin cancer: a composite death certificate based case-control study. Occup Environ Med 2002, 59:257-262.

II. Vishvakarman D, Wong JC: Description of the use of a risk estimation model to assess the increased risk of non-melanoma skin cancer among outdoor workers in Central Queensland, Australia. Photodermatol Photoimmunol Photomed 2003, 19:8I-88.

12. Rosales-Castillo JA, Acosta-Saavedra LC, Torres R, Ochoa-Fierro J, Borja-Aburto VH, Lopez-Carrillo L, Garcia-Vargas GG, Gurrola GB, Cebrian ME, Calderon-Aranda ES: Arsenic exposure and human papillomavirus response in non-melanoma skin cancer Mexican patients: a pilot study. Int Arch Occup Environ Health 2004, 77:418-423.
13. IARC: Arsenic. 2004 [http://monographs.iarc.fr/ENG/Monographs/ vol84/volume84.pdf]. IARC Scientific Publications

14. Salazar AM, Calderon-Aranda E, Cebrian ME, Sordo M, Bendesky A, Gomez-Munoz A, Acosta-Saavedra L, Ostrosky-Wegman P: p53 expression in circulating lymphocytes of non-melanoma skin cancer patients from an arsenic contaminated region in Mexico. A pilot study. Mol Cell Biochem 2004, 255:25-3I.

15. Gallagher RP, Bajdik CD, Fincham S, Hill GB, Keefe AR, Coldman A, McLean DI: Chemical exposures, medical history, and risk of squamous and basal cell carcinoma of the skin. Cancer Epidemiol Biomarkers Prev 1996, 5:419-424.

16. Pfister H: Human Papillomaviruses and Skin Cancer. Journal of National Cancer Institute Monographic; 2006:52-56.

17. Saladi RN, Persaud AN: The causes of skin cancer: a comprehensive review. Drugs Today (Barc) 2005, 4 I:37-53.

18. Wong CS, Strange RC, Lear JT: Basal cell carcinoma. BMJ 2003, 327:794-798.

19. Gawkrodger DJ: Occupational skin cancers. Occup Med (Lond) 2004, 54:458-463.

20. Karagas MR, Cushing GL Jr, Greenberg ER, Mott LA, Spencer SK, Nierenberg DW: Non-melanoma skin cancers and glucocorticoid therapy. BrJ Cancer 200I, 85:683-686.

21. Nokso-Koivisto P, Pukkala E: Past exposure to asbestos and combustion products and incidence of cancer among Finnish locomotive drivers. Occup Environ Med 1994, 5 1:330-334.

22. Tolbert PE: Oils and cancer. Cancer Causes Control 1997, 8:386-405.

23. Vogt A, Hebert J, Hwang J, Lu Y, Epstein EH: Anti-rejection drug treatment increases basal cell carcinoma burden in PtchI+1mice. J Invest Dermatol 2005, 1 24:263-267.

24. Wechsler J, Zanetti R, Schrameck C, Rosso S, Pippione M, Linares J, Laurent R, Ortuno G, Boi S, Gafa L, Joris F, Spatz A, Barneon G, Sacerdote $\mathrm{C}$, Sancho-Garnier $\mathrm{H}$ : Reproducibility of histopathologic diagnosis and classification of non-melanocytic skin cancer: a panel exercise in the framework of the multicenter southern European study HELIOS. Tumori 200I, 87:95-I00.

25. ILO: International Standard Classification of Occupations, 1968 edn 1968.

26. Zanetti R, Rosso S, Martinez C, Nieto A, Miranda A, Mercier M, Loria DI, Osterlind A, Greinert R, Navarro C, Fabbrocini G, Barbera C, SanchoGarnier H, Gafa L, Chiarugi A, Mossotti R: Comparison of risk patterns in carcinoma and melanoma of the skin in men: a multicentre case-case-control study. Br J Cancer 2006, 94:743-75I.

27. Brown HPR: Applied Mixed Models in Medicine, 2004 edn Chichester: Wiley; 2004

28. Kennedy C, Bajdik CD, Willemze R, Bouwes Bavinck JN: Chemical exposures other than arsenic are probably not important risk factors for squamous cell carcinoma, basal cell carcinoma and malignant melanoma of the skin. Br J Dermatol 2005, 152: 194- 197.

29. Denman AR, Eatough JP, Gillmore G, Phillips PS: Assessment of health risks to skin and lung of elevated radon levels in abandoned mines. Health Phys 2003, 85:733-739.

30. Karagas MR, McDonald JA, Greenberg ER, Stukel TA, Weiss JE, Baron JA, Stevens MM: Risk of basal cell and squamous cell skin cancers after ionizing radiation therapy. For The Skin Cancer Prevention Study Group. J Natl Cancer Inst 1996, 88: I848-I853.

31. Begraca M, Ukmata H, Morris SC, Canhasi B, Haxhiu MA: Study of early appearance of skin lesions in coal gasification workers. Arh Hig Rada Toksikol 199I, 42:287-294.

32. Rosengren $A$, Wilhelmsen $L:$ Cancer incidence, mortality from cancer and survival in men of different occupational classes. Eur J Epidemiol 2004, 19:533-540.

33. Floderus B, Stenlund C, Persson T: Occupational magnetic field exposure and site-specific cancer incidence: a Swedish cohort study. Cancer Causes Control 1999, 10:323-332.

34. Lichter MD, Karagas MR, Mott LA, Spencer SK, Stukel TA, Greenberg ER: Therapeutic ionizing radiation and the incidence of basal cell carcinoma and squamous cell carcinoma. The New Hampshire Skin Cancer Study Group. Arch Dermatol 2000, 136:1007-1011.

35. Ron E, Preston DL, Kishikawa M, Kobuke T, Iseki M, Tokuoka S, Tokunaga M, Mabuchi K: Skin tumor risk among atomic-bomb survivors in Japan. Cancer Causes Control 1998, 9:393-40I.

36. Shore RE: Overview of radiation-induced skin cancer in humans. Int J Radiat Biol 1990, 57:809-827.

37. Aubry F, MacGibbon B: Risk factors of squamous cell carcinoma of the skin. A case-control study in the Montreal region. Cancer 1985, 55:907-91।. 
38. Hogan DJ, To T, Gran L, Wong D, Lane PR: Risk factors for basal cell carcinoma. Int J Dermatol 1989, 28:59I-594.

39. Hogan DJ, Lane PR, Gran L, Wong D: Risk factors for squamous cell carcinoma of the skin in Saskatchewan, Canada. J Dermatol Sci 1990, I:97-101.

40. Rosso S, Joris F, Zanetti R: Risk of basal and squamous cell carcinomas of the skin in Sion, Switzerland: a case-control study. Tumori 1999, 85:435-442.

41. Blair A, Zahm SH: Agricultural exposures and cancer. Environ Health Perspect 1995, I03(Suppl 8):205-208.

42. Rosso S, Minarro R, Schraub S, Tumino R, Franceschi S, Zanetti R: Reproducibility of skin characteristic measurements and reported sun exposure history. Int J Epidemiol 2002, 31 :439-446.

43. IARC: Human papillomaviruses. 2007 [http://monographs.iarc.fr/ ENG/Meetings/vol90.php]. IARC Scientific Publications

\section{Pre-publication history}

The pre-publication history for this paper can be accessed here:

http://www.biomedcentral.com/1471-2458/7/180/prepub

Publish with Biomed Central and every scientist can read your work free of charge

"BioMed Central will be the most significant development for disseminating the results of biomedical research in our lifetime. "

Sir Paul Nurse, Cancer Research UK

Your research papers will be:

- available free of charge to the entire biomedical community

- peer reviewed and published immediately upon acceptance

- cited in PubMed and archived on PubMed Central

- yours - you keep the copyright

Submit your manuscript here:

http://www.biomedcentral.com/info/publishing_adv.asp
BioMedcentral 